\title{
Imazapyr HeRbicide EfFicacy ON FloAting Macrophyte CONTROL AND ECOTOXICOLOGY FOR NON-TARGET ORGANISMS ${ }^{1}$
}

\author{
Eficácia do Herbicida Imazapyr no Controle de Macrófitas Flutuantes e Ecotoxicologia para \\ Organismos Não Alvos
}

CRUZ, C. ${ }^{2,3}$, SILVA, A.F. ${ }^{3}$, SHIOGIRI, N.S. ${ }^{3}$, GARLICH, N. ${ }^{3}$, and PITELLI, R.A. ${ }^{3}$

\begin{abstract}
- the aims of this study were to determine imazapyr efficacy for floating macrophyte control and ecotoxicology for non-target organisms. For the floating macrophyte control efficacy tests were used the doses of 0,$5 ; 1,0 ; 2,0 ; 2,5 ; 3,0 ; 3,5$ and $4,0 \mathrm{~L} \mathrm{ha}^{-1}$ and a control with 10 replicates. The acute toxicology for non-target organisms was estimated by lethal concentration 50\% (LC50 and EC50). The floating macrophyte control efficacy was over $90 \%$. Imazapyr was classified as moderately toxic for the following biomarkers: L. minor, H. eques, $B$. rerio, $P$. caudimaculatus, $P$. canaliculata, and $P$. mesopotamicus and lightly toxic for $A$. caroliniana. Thus, imazapyr herbicide is a tool with great potential to be used on floating macrophyte control (E. crassipes, P. stratiotes e S. molesta) in Brazil and this practice can be evaluated by the use of application biomarkers.
\end{abstract}

Keywords: acute toxicology, biomarkers, aquatic plants management.

RESUMO - O objetivo deste estudo foi determinar a eficácia do imazapyr no controle de macrófitas flutuantes e a ecotoxicidade para organismos não alvos. Para os ensaios de eficácia de controle das macrófitas flutuantes, foram utilizadas as doses de 0,5; 1,0; 2,0; 2,5; 3,0; 3,5 e 4,0 L hal e um controle com 10 réplicas. A toxicidade aguda para organismos não alvos foi estimada pela concentração letal de 50\% (CL5O e CE50). A eficácia de controle para as macrófitas flutuantes foi acima de $90 \%$. O imazapyr foi classificado como moderadamente tóxico para os bioindicadores $\boldsymbol{L}$. minor, $\boldsymbol{H}$. eques,

B. rerio, $\boldsymbol{P}$. caudimaculatus, $\boldsymbol{P}$. canaliculata e $\boldsymbol{P}$.mesopotamicus e ligeiramente tóxico para A. caroliniana. Assim, o herbicida imazapyr é uma ferramenta com grande potencial para ser usada no controle de macrófitas flutuantes (E. crassipes, $\boldsymbol{P}$. stratiotes e $\mathbf{S}$. molesta) no Brasil, e a sua utilização pode ser avaliada por meio de bioindicadores de aplicação.

Palavras-chave: toxicidade aguda, bioindicação, manejo de plantas aquáticas.

\section{INTRODUCTION}

The macrophyte colonization problem has grown, especially on hydroelectric reservoir and waterways, which have their activities, compromised by submersed, emerged and floating macrophytes infestation, being necessary the intervention for plants control and management (Hanlon \& Langeland, 2000).
The studies about macrophyte control using herbicide are well known in some countries, and several data were obtained under laboratory condition in Brazil (Henares et al., 2009), although there are few available results about the products toxicity on non target organisms, which can be used as application biomarkers (Botelho et al., 2009), besides the determination of efficacy control,

1 Recebido para publicação em 3.10.2014 e aprovado em 19.11.2014.

2 Centro Universitário da Fundação Educacional de Barretos, Barretos-SP, Brasil, <claudineicruz@gmail.com>; ${ }^{3}$ Núcleo de Estudos e Pesquisas Ambientais em Matologia, UNESP, Jaboticabal-SP, Brasil. 
which could enable the rational use of herbicides on macrophyte control.

Among herbicides which may be applied on water bodies, an inhibitor of the enzyme acetolactate synthase (ALS) or acetohydroxicacid sinthase (AHAS) called imazapyr is used on agriculture, due to its weed control efficacy, low recommended doses, low toxicity on mammals and selectivity is approved, since 2003 in the United States, for aquatic weed control (Mozdzer et al., 2008).

To apply herbicides in aquatic environments, knowledge of its environmental dynamics and toxicity on non-target organisms is necessary. The herbicides ecotoxicological effects on organisms were described for fish (Miron et al., 2004), Lemna minor (Coutris et al., 2011), Azolla caroliniana (Bennicelli et al., 2004), amphibians (Navarro-Martín et al., 2014), among others.

There is in Brazil a discussion between regulatory agencies as actors on environmental management about the feasibility of macrophyte chemical control with herbicides. In this context, it is important to assess the environmental security, dose/ concentration, exposure time, molecule degradation on neotropical conditions, effects on non-target organisms of imazapyr, a herbicide with macrophyte control potential.

Thus, the aims of this study were to determine imazapyr efficacy on floating macrophyte control (Eichhornia crassipes, Pistia stratiotes and Salvinia molesta), acute toxicity (LC50 and EC50) for red tetra fish (Hyphessobrycon eques), zebrafish (Brachydanio rerio), guaru (Phallocerus caudimaculatus) and pacu (Piaractus mesopotamicus), for common duckweed (Lemna minor) and water velvet (Azolla caroliniana) and for snail (Pomacea canaliculata), used as potential biomarkers for herbicides application effects.

\section{MATERIAL AND METHODS}

\section{Efficacy assay on macrophyte control}

The macrophytes (E. crassipes, $P$. stratiotes and $S$. molesta) were grown in 2.5 liters plastic boxes containing water and substratum composed by soil, sand and organic compound based on Plantmax ${ }^{\circledR}\left(2: 1: 1 ; \mathrm{vv}^{-1}\right)$. The growing plants were kept for 30 days under greenhouse conditions for growth.

After this period, imazapyr was applied at the following doses: $0.5 ; 1.0 ; 2.0$; $2.5 ; 3.0 ; 3.5 ;$ e $4.0 \mathrm{~L} \mathrm{ha}^{-1}$, corresponding to $125.0 ; 250.0 ; 500.0 ; 625.0 ; 750.0$; $875.0 ; 1000.0 \mathrm{~g}$ a.i. ha ${ }^{-1}$ concentrations, with 10 replicates per treatment in a completely randomized design (CRD). The applications were made with backpack precision sprayer, on constant pressure of 25 psi, sustained by $\mathrm{CO}_{2}$ and $200.0 \mathrm{~L} \mathrm{ha}^{-1}$, using spray bar with flat spray nozzles $8002 \mathrm{E}$. The application conditions were: $20.5{ }^{\circ} \mathrm{C}$; 0.8 to $2.0 \mathrm{~km} \mathrm{ha}^{-1}$ winds and relative humidity at $63.0 \%$.

The evaluations were composed by control ranks, according to the rate proposed by Velini et al. (1995), at 3, 7, 15, 21, 30, 45 and 60 days after application (DAA).

\section{Ecotoxicological assay on fish and snail}

The quota of test organisms with 1.0 to $3.0 \mathrm{~g}$ weight for fish and 2.0 to $3.0 \mathrm{~g}$ for snail, were acclimated for seven days in bioassay room, with controlled conditions (ABNT, 2011). The concentrations used to determine the acute toxicity of imazapyr were as follows: $2.5 ; 3.0 ; 3.5 ; 4.0$ and $4.5 \mathrm{mg} \mathrm{L}^{-1}$ for H. eques: $3.0 ; 4.0 ; 5.0 ; 6.0$ and $7.0 \mathrm{mg} \mathrm{L}^{-1}$ for P. caudimaculatus; $1.0 ; 3.0 ; 5.0$; and $7.0 \mathrm{mg} \mathrm{L}^{-1}$ for $B$. rerio and $7.50 ; 7.75 ; 8.00 ; 8.25$ and $8.50 \mathrm{mg} \mathrm{L}^{-1}$ for P. mesopotamicus and a control, with three replicates, with $1.0 \mathrm{~g} \mathrm{~L}^{-1}$ maximum density. The concentrations tested on snails were $1.0 ; 3.0 ; 5.0 ; 7.0 ; 10.0$ and $15.0 \mathrm{mg} \mathrm{L}^{-1}$ and a control with three replicates and five animals per replicate.

The initial variables of water quality were: $\mathrm{pH}$ between 6.5 and 7.5 ; dissolved oxygen above $4.0 \mathrm{mg} \mathrm{L}^{-1}$; electrical conductivity from 170.0 to $180.0 \mu \mathrm{S} \mathrm{cm}^{-1}$; hardness from 10.0 to $60.0 \mathrm{mg} \mathrm{CaCO}_{3} \mathrm{~L}^{-1}$ and alkalinity from 200.0 to $210.0 \mathrm{mg} \mathrm{CaCO}_{3}$ (ABNT, 2011). The tests were conducted on a static system. The mortality (fish) and immobility (snails) tests were evaluated at 24 and 48 hours after herbicide exposure. The acute (LC50; 48h) and effective (EC50; 48h) toxicity were calculated 
by Trimmed Spearman-Karber software (Hamilton et al., 1977).

\section{Ecotoxicological assay for macrophytes}

The macrophyte was acclimated in bioassay room, at $25.0 \pm 2.0{ }^{\circ} \mathrm{C}$ temperature and under constant light with 1000.0 lux for three days. After the acclimatization, the plants were disinfected with an aqueous solution of sodium hypochlorite $2 \%$ (L. minor) and $3 \%(A$. caroliniana $)$ and distilled water. Then, four plants were selected with three fronds per colony (12 fronds) for L. minor and for A. caroliniana five plants were selected, both in glass container, with $100 \mathrm{~mL}$ capacity, containing $50 \mathrm{~mL}$ of Hoagland's culture medium with herbicide.

The doses used on L. minor were $0.5 ; 1.0$; $2.0 ; 4.0 ; 8.0 ; 16.0$ e $32.0 \mathrm{mg} \mathrm{L}^{-1}$ and on A. caroliniana $10.0 ; 20.0 ; 30.0 ; 40.0 \mathrm{e}$ $50.0 \mathrm{mg} \mathrm{L}^{-1}$, both with a control and three replicates per concentration. The plant mortality was evaluated at 3, 5 and 7 days after exposure. L. minor was evaluated accordingly to changes in growth rate and fronds number (OECD, 2002). On A. caroliniana was used a grading scale (E to A) accordingly to Silva et al. (2012). The acute toxicity (LC50; 7d) was calculated by Trimmed Spearman-Karber software (Hamilton et al., 1977).

\section{RESULTS AND DISCUSSION}

On the imazapyr application for macrophyte control occurred leaves yellowing,

Table 1 - Control percentage of E. crassipes on exposure to imazapyr during the trial

\begin{tabular}{|c|r|r|r|r|r|r|r|r|}
\hline Dose & \multicolumn{7}{|c|}{ Days after application } \\
\hline$\left(\mathrm{L} \mathrm{ha}^{-1}\right)$ & 3 & 7 & 15 & 21 & 30 & 45 & 60 \\
\hline \multicolumn{8}{|c|}{ Mortality (\%) } \\
\hline 0.0 & 0 & 0 & 0 & 0 & 0 & 0 & 0 \\
\hline 0.5 & 10 & 10 & 10 & 50 & 40 & 50 & 50 \\
\hline 1.0 & 10 & 20 & 20 & 50 & 80 & 80 & 80 \\
\hline 2.0 & 10 & 20 & 20 & 50 & 80 & 80 & 80 \\
\hline 2.5 & 20 & 20 & 40 & 70 & 80 & 80 & 90 \\
\hline 3.0 & 20 & 30 & 30 & 70 & 80 & 90 & 90 \\
\hline 3.5 & 20 & 20 & 40 & 80 & 90 & 90 & 100 \\
\hline 4.0 & 30 & 40 & 40 & 80 & 90 & 90 & 100 \\
\hline
\end{tabular}

followed by necrosis and plants death (E. crassipes e P. stratiotes) and on S. molesta occurred leaves yellowing and partial plant necrosis at 60 DAA for 875.0 e $1000.0 \mathrm{~g} \mathrm{ha}^{-1}$ doses.

The control on E. crassipes ranged from no control to unsatisfying control (0 to $70 \%$ ) for all evaluated concentration at 3,7 and 15 DAA (Table 1). At 21 DAA the 875.0 and $1000.0 \mathrm{~g} \mathrm{ha}^{-1}$ doses showed good control efficacy $(80 \%)$, whereas, for 125.0 and $750.0 \mathrm{~g} \mathrm{ha}^{-1}$ doses the control was unsatisfying (50 to $70 \%$ ). At 30 and 45 DAA the control was good for 250.0; 500.0; 625.0; 875.0 e $1000.0 \mathrm{~g} \mathrm{ha}^{-1}$ doses (80 and $90 \%$ ) and at 60 DAA the control efficacy was excellent with 875.0 and $1000.0 \mathrm{~g} \mathrm{ha}^{-1}$ $(100 \%)$ and for 625.0 e $750.0 \mathrm{~g} \mathrm{ha}^{-1}$ doses the efficacy control was considered good $(90 \%)$ (Table 1).

For $P$. stratiotes, ranged from no control to unsatisfying control (0 to 70\%) for all evaluated concentration at 3, 7 and 15 DAA (Table 2). At 30 DAA the control efficacy ranged from unsatisfactory with 125.0 to $750.0 \mathrm{~g} \mathrm{ha}^{-1}$ to satisfactory with 850.0 and $1000.0 \mathrm{~g} \mathrm{ha}^{-1}$ (60 to 70 and $80 \%$, respectively). After 45 DAA the infestation control was excellent with 850.0 and $1000.0 \mathrm{~g} \mathrm{ha}^{-1}$ (95 to $100 \%$ ) and with 625.0 and $750.0 \mathrm{~g} \mathrm{ha}^{-1}$ the control efficacy was considered good at 60 DAA (90\%) (Table 2).

For S. molesta, ranged from no control to unsatisfying control (0 to $70 \%$ ) for all evaluated concentration at 3, 7 and 15 DAA (Table 3). At 30 DAA the control was unsatisfactory (60 to $70 \%$ ) with $625.0 ; 750.0 ; 875.0$ and

Table 2 - Control percentage of $P$. stratiotes on exposure to imazapyr during the trial

\begin{tabular}{|c|r|r|r|r|r|r|r|r|}
\hline Dose & \multicolumn{7}{|c|}{ Days after application } \\
\hline$\left(\mathrm{L} \mathrm{ha}^{-1}\right)$ & 3 & 7 & 15 & 21 & 30 & 45 & 60 \\
\hline \multicolumn{8}{|c|}{ Mortality (\%) } \\
\hline 0.0 & 0 & 0 & 0 & 0 & 0 & 0 & 0 \\
\hline 0.5 & 10 & 20 & 30 & 30 & 60 & 70 & 70 \\
\hline 1.0 & 10 & 20 & 30 & 40 & 60 & 60 & 70 \\
\hline 2.0 & 10 & 20 & 30 & 40 & 60 & 80 & 80 \\
\hline 2.5 & 20 & 20 & 40 & 40 & 60 & 80 & 90 \\
\hline 3.0 & 20 & 20 & 40 & 40 & 60 & 80 & 90 \\
\hline 3.5 & 20 & 40 & 40 & 70 & 80 & 95 & 95 \\
\hline 4.0 & 20 & 40 & 40 & 70 & 80 & 100 & 100 \\
\hline
\end{tabular}


$1000.0 \mathrm{~g} \mathrm{ha}^{-1}$ doses. At 45 and 60 DAA with $1000.0 \mathrm{~g} \mathrm{ha}^{-1}$ good control efficacy (90\%) has occurred. At the period, the doses 625.0 to $875.0 \mathrm{~g} \mathrm{ha}^{-1}$ showed satisfactory control (60 and $70 \%$, respectively) (Table 3 ), as recommendation table for evaluation of efficacy of herbicides (Velini et al., 1995).

The better control efficacy percentage for imazapyr has occurred with $1000.0 \mathrm{~g} \mathrm{ha}^{-1}$ for all three macrophyte, with control considered excellent (above 90\%). Similar control was observed for Pistia stratiotes, Eichhornia crassipes, Salvinia auriculata, Myriophyllum aquaticum, Brachiaria arrecta, Hydrocotyle umbelatta (above 95\%) and Typha sp. (above 90\%) with $1250.0 \mathrm{~g} \mathrm{ha}^{-1}$ dose of the same herbicide (Foloni \& Pitelli, 2005). For Panicum repens control, around the Okeechobee lake, Florida, imazapyr showed 60 to $100 \%$ efficacy with 560.0 and $840.0 \mathrm{~g} \mathrm{ha}^{-1}$ application (Hanlon and Langeland, 2000).

The most tolerant macrophyte on this test was S. molesta. This species also showed control difficulty for the same herbicide (1680.0 $\left.\mathrm{g} \mathrm{ha}^{-1}\right)$ and for endothall (5040.0 $\left.\mathrm{g} \mathrm{ha}^{-1}\right)$. The control was effective with glyphosate (8970.0 $\mathrm{g} \mathrm{ha}^{-1}$ ), diquat (1120.0 to $2240.0 \mathrm{~g} \mathrm{ha}^{-1}$ ), copper $\left(4490.0 \mathrm{~g} \mathrm{ha}^{-1}\right)$ and the endothall + diquat, endothall + glyphosate e imazapy + glyphosate combinations, indicating that the use of two action mechanisms may be more effective o n S. molesta control (Nelson et al., 2001).

Accordingly to Fairchild et al. (2002), a control alternative for $S$. molesta may be a surfactant addition. The usage of $2.8 \mathrm{~L} \mathrm{ha}^{-1}$ glyphosate $+0.25 \%$ of Optima ${ }^{\circledR}$ surfactant
Table 3 - Control percentage of S. molesta on exposure to imazapyr during the trial

\begin{tabular}{|c|r|r|r|r|r|r|r|}
\hline Dose & \multicolumn{7}{|c|}{ Days after application } \\
\hline$\left(\mathrm{L} \mathrm{ha}^{-1}\right)$ & 3 & 7 & 15 & 21 & 30 & 45 & 60 \\
\hline \multicolumn{8}{|c|}{ Mortality (\%) } \\
\hline 0.0 & 0 & 0 & 0 & 0 & 0 & 0 & 0 \\
\hline 0.5 & 0 & 10 & 30 & 30 & 40 & 40 & 40 \\
\hline 1.0 & 0 & 10 & 40 & 40 & 40 & 50 & 50 \\
\hline 2.0 & 0 & 20 & 50 & 50 & 50 & 50 & 50 \\
\hline 2.5 & 0 & 40 & 50 & 50 & 60 & 60 & 60 \\
\hline 3.0 & 0 & 50 & 60 & 60 & 60 & 60 & 70 \\
\hline 3.5 & 20 & 50 & 60 & 60 & 70 & 70 & 70 \\
\hline 4.0 & 20 & 50 & 70 & 70 & 70 & 90 & 90 \\
\hline
\end{tabular}

caused complete death pf this macrophyte, with full depigmentation at 42 DAA. The lower sensitivity of $S$. molesta to imazapyr has probably occurred due to the presence of foliar trichomes at the adaxial surface, which negatively interfered the herbicide absorption (Gettys et al., 2009).

The estimated acute toxicity (LC50;7d) for $L$. minor was $1.06 \mathrm{mg} \mathrm{L}^{-1}$ (Table 4) with $11 \%$ mortality on $0.5 \mathrm{mg} \mathrm{L}^{-1} ; 33 \%$ on $1.0 \mathrm{mg} \mathrm{L}^{-1} ; 64 \%$ on $2.0 \mathrm{mg} \mathrm{L}^{-1} ; 75 \%$ on $4.0 \mathrm{mg} \mathrm{L}^{-1}$; and $100 \%$ on $8.0 \mathrm{mg} \mathrm{L}^{-1}$. For $A$. caroliniana, the LC50;7d was $18.9 \mathrm{mg} \mathrm{L}^{-1}$ (Table 4), with $13,3 \%$ mortality on $10.0 \mathrm{mg} \mathrm{L}^{-1} ; 46.6 \%$ on $20.0 \mathrm{mg} \mathrm{L}^{-1} ; 83 \%$ on $30.0 \mathrm{mg} \mathrm{L}^{-1} ; 95 \%$ on $40.0 \mathrm{mg} \mathrm{L}^{-1}$; and $100 \%$ mortality on $50.0 \mathrm{mg} \mathrm{L}^{-1}$.

The main discussion about herbicide usage in aquatic environments is the possible application environmental effects, as the effects on non target organisms, in addition to a lack of efficacy proofs. The most sensible

Table 4 - Acute toxicity (mg L ${ }^{-1}$ ) of imazapyr for non target organisms

\begin{tabular}{|l|c|c|c|c|c|}
\hline \multicolumn{1}{|c|}{ Biomarker } & Upper Limit & $\begin{array}{c}\text { CL50 and } \\
\text { CE50 }\end{array}$ & Lower limit & $\mathrm{R}^{2}$ & Linear equation \\
\hline L. minor & 1,28 & 1,06 & 0,88 & 0,91 & $\mathrm{y}=5,2176 \mathrm{x}+6,0826$ \\
\hline A. caroliniana & 20,61 & 18,98 & 17,48 & 0,94 & $\mathrm{y}=2,2333 \mathrm{x}+0,5548$ \\
\hline H. eques & 4,23 & 3,93 & 3,68 & 0,92 & $\mathrm{y}=53,338 \mathrm{x}-144,46$ \\
\hline B. rerio & 5,10 & 4,35 & 3,72 & 0,99 & $\mathrm{y}=14,295 \mathrm{x}-3,5244$ \\
\hline P. caudimaculatus & 6,11 & 5,30 & 4,62 & 0,98 & $\mathrm{y}=14,336 \mathrm{x}-6,1995$ \\
\hline P. mesopotamicus & 8,34 & 8,19 & 8,06 & 0,93 & $\mathrm{y}=88,068 \mathrm{x}-656,38$ \\
\hline P. canaliculata & 7,14 & 5,89 & 4,86 & 0,91 & $\mathrm{y}=7,2307 \mathrm{x}-1,3988$ \\
\hline
\end{tabular}


biomarker to imazapyr was L. minor, with similar sensibility to $L$. trisulca exposed to methyl-metsulfuron (LC50;7d $=1.04 \mathrm{mg} \mathrm{L}^{-1}$ ) (Cedergreen et al., 2004) and L. minor and A. filiculoides $\left(0.6 \mathrm{mg} \mathrm{L}^{-1}\right)$ exposed to $50 \%$ atrazine, $35 \%$ isoproturon e $15 \%$ alachlor mixtures (Coutris et al., 2011). A. caroliniana has showed higher sensibility to imazapyr, compares to oxyfluorfen $\left(80.5 \mathrm{mg} \mathrm{L}^{-1}\right)$ and clomazone (129.6 $\mathrm{mg} \mathrm{L}^{-1}$ ) (Silva et al., 2012).

The acute toxicity (LC50;96h) for $H$. eques was $3.9 \mathrm{mg} \mathrm{L}^{-1}$ (Table 4). After imazapyr exposure, has occurred no mortality on the control and on $2.5 \mathrm{mg} \mathrm{L}^{-1}$. On $3.0 \mathrm{mg} \mathrm{L}^{-1}$ the mortality rate was $11.1 \%$; on $3.5 \mathrm{mg} \mathrm{L}^{-1}$ was $22.2 \%$; on $4.0 \mathrm{mg} \mathrm{L}^{-1}$ was $77.8 \%$ and on $4.5 \mathrm{mg} \mathrm{L}^{-1}$ occurred $100 \%$ mortality. For $B$. rerio the LC50;96h was $4.3 \mathrm{mg} \mathrm{L}^{-1}$ (Table 4). After the exposure, $11.1 \%$ mortality has occurred on $1.0 \mathrm{mg} \mathrm{L}^{-1}$. On $3,0 \mathrm{mg} \mathrm{L}^{-1}$ the mortality rate was $33.3 \%$; on $5.0 \mathrm{mg} \mathrm{L}^{-1}$ was $66.6 \%$; and on $7.0 \mathrm{mg} \mathrm{L}^{-1}$ the mortality rate was $100 \%$.

For $P$. caudimaculatus the LC50;96h was $5.3 \mathrm{mg} \mathrm{L}^{-1}$ (Table 4) with $5.0 \%$ mortality on $1.0 \mathrm{mg} \mathrm{L}^{-1}, 33 \%$ on $3.0 \mathrm{mg} \mathrm{L}^{-1}, 60.0 \%$ on $5.0 \mathrm{mg} \mathrm{L}^{-1}$ and $100.0 \%$ mortality on $7.0 \mathrm{mg} \mathrm{L}^{-1}$. The LC50;96h for P. mesopotamicus was $8.1 \mathrm{mg} \mathrm{L}^{-1}$ (Table 4). After the exposure to imazapyr no mortality occurred on $7.5 \mathrm{mg} \mathrm{L}^{-1}$. On $7.7 \mathrm{mg} \mathrm{L}^{-1}$ the mortality rate was $35.3 \%$; on $8.0 \mathrm{mg} \mathrm{L}^{-1}$ was $50 \%$; on $8.2 \mathrm{mg} \mathrm{L}^{-1}$ was $55.5 \%$ and on $8.5 \mathrm{mg} \mathrm{L}^{-1}$ the mortality rate was $100 \%$.

The acute toxicity (EC50;48h) for P. caniculata was $5.8 \mathrm{mg} \mathrm{L}^{-1}$ (Table 4), with $6.7 \%$ mortality on $3.0 \mathrm{mg} \mathrm{L}^{-1} ; 40.0 \%$ on $5.0 \mathrm{mg} \mathrm{L}^{-1} ; 73.3 \%$ on $7.0 \mathrm{mg} \mathrm{L}^{-1} ; 66.7 \%$ on $10.0 \mathrm{mg} \mathrm{L}^{-1}$; and $100 \%$ on $15.0 \mathrm{mg} \mathrm{L}^{-1}$.

Accordingly to the ecotoxicological ranking from Zucker \& Johnson (1985), the tested imazapyr can be considered moderately toxic for fish, L. minor and snails, whereas for A. caroliniana was considered lightly toxic (LC50 from 10 to $100 \mathrm{mg} \mathrm{L}^{-1}$ ). The imazapyr exposed fish showed similar sensible answer to Danio rerio and Poecilia reticulate with terbutryn exposure $\left(5.7 \mathrm{mg} \mathrm{L}^{-1}\right)$ (Plhalova et al., 2010), and to to $P$. caudimaculatus for diquat (7.1 $\left.\mathrm{mg} \mathrm{L}^{-1}\right)$ (Henares et al., 2011).
The bioindicator which can be used on the management of imazapyr application, in decreasing order, were as follows: L. minor $>H$. eques $>B$. rerio $>P$. caudimaculatus $>$ P. canaliculata $>$ P. mesopotamicus > A. caroliniana.

Imazapyr belongs to the imidazolinone group, with action mechanism consisting in the inhibition of acetolactate synthase (ALS) or acetohydroxyacid synthase (AHAS) from primary producer.

Imazapyr showed excellent control efficacy for floating macrophytes, with systemic action and promoting a relatively slow death for the plants, lowering the effects of organic matter decomposition, which can cause direct alterations at the environmental compartment of the primary producers (L. minor and A. caroliniana) and for other organisms, like fish ( $H$. eques, $B$. rerio and $P$. caudimaculatus), considered sensible species to the effects of chemical products (Cruz et al., 2008).

For regulatory purposes of herbicide usage on aquatic environments, besides the use of toxicity biomarkers organisms or the establishment of monitoring programs, accordingly to Siemering et al. (2008) is also necessary to change the composition of agricultural products, specially the surfactant type, in order to lower the environmental risk of the chemical macrophyte control. Thus, the imazapyr herbicide is a tool with great potential for floating macrophyte control (E. crassipes, $P$. stratiotes and $S$. molesta) in Brazil, and the use of this molecule can be evaluated through application biomarkers use.

\section{LITERATURE CITED}

ASSOCIAÇÃO BRASILEIRA DE NORMAS TÉCNICAS ABNT. NBR 15088: Ecotóxicologia aquática - Toxidade aguda - Método de ensaio com peixes. São Paulo: 2011. 19 p.

BENNICELLI, R. The ability of Azolla caroliniana to remove heavy metals (Hg(II), Cr(III), $\mathrm{Cr}(\mathrm{VI})$ ) from municipal waste water. Chemosphere, v. 55, n. 1, p. 141-146, 2004.

BOTELHO, R. G. et al. Toxicidade aguda de herbicidas a tilápia (Oreochromis niloticus). Planta Daninha, v. 27, n. 3, p. 621-626, 2009.

CEDERGREEN, N. et al. Species-specific sensivity of aquatic macrophytes towards two herbicide. Ecotoxicol. Environ. Safety, v. 58, n. 3, p. 314-323, 2004. 
COUTRIES, C. et al. Can we predict community-wide effect of herbicides from toxicity tests on macrophytes species. Aquatic Toxicol., v. 101, n. 1, p. 40-56, 2011.

CRUZ, C. et al. Sensibilidade de peixes neotropicais ao dicromato de potássio. J. Braz. Soc. Ecotoxicol., v. 3, n. 1, p. 53-55, 2008.

FAIRCHILD, J. F. et al. Efficacy of glyphosate and five surfactants for controlling giant Salvinia. J. Aquatic Plant Manag., v. 40, n. 1, p. 53-58, 2002.

FOLLONI, L. L.; PITELLI, R. A. Avaliação da sensibilidade de diversas espécies de plantas daninhas aquáticas ao carfetrazone-ethyl, em ambientes controlados.

Planta Daninha, v. 23, n. 2, p. 329-334, 2005.

GETTYS, L. A. et al. Biology and control of aquatic plants. Marietta GA: Aquatic Ecosystem Restoration Foundation, 2009. 210 p. (Best management practices handbook de 2009)

HAMILTON, M. A. et al. Trimmed Spearman-Karber method for estimating median lethal concentrations in toxicity bioassays. Environ. Sci. Technol., v. 11, n. 7, p. 714-719, 1977.

HANLON, C. G.; LANGELAND, K. Comparison of experimental strategies to control torpedograss. J. Aquatic Plant Manag., v. 38, n. 1, p. 40-47, 2000.

HENARES, M. N. P. et al. Eficácia do diquat no controle de Hydrilla verticillata, Egeria densa e Egeria najas e toxicidade aguda para o guaru (Phallocerus caudimaculatus), em condições de laboratório. Planta Daninha, v. 29, n. 2, p. 279-285, 2011.

MIRON, D. S. et al. Lethal concentration of clomazone, metsulfuron-metil, and quinclorac for silver catfish, Rhamdia quelen, fingerlings. Ci. Rural, v. 34, n. 5, p. 1465-1469, 2004.
MOZDZER, T. J. et al. Efficacy of imazapyr and glyphosate in the control of non-native Phragmites australis. Restor. Ecol., v. 16, n. 2, p. 221-224, 2008.

NAVARRO-MARTÍN, A. L. et al. Effects of glyphosatebased herbicides on survival, development, growth and sex ratios of wood frogs (Lithobates sylvaticus) tadpoles. I: Chronic laboratory exposures to VisionMax ${ }^{\circledR}$.

Aquatic Toxicol. 2014. In press.

NELSON, L. S. et al. Herbicide evaluation against giant salvinia. J. Aquatic Plant Mang., v. 39, n. 1, p. 48-43, 2001.

ORGANIZATION FOR ECONOMIC CO-OPERATION AND DEVELOPMENT - OECD. Guidelines for the Testing of Chemicals, Lemna sp. Growth inhibition test. Paris, France, 2002. 22 p.

PLHALOVÁ, L. et al. Comparison of terbutryn acute toxicity to Danio rerio and Poecilia reticulate. Acta Vet. BRNO, v. 79, n. 4, p. 593-598, 2010.

SIEMERING, G. S. et al. Assessment of potential aquatic herbicide impacts to California aquatic ecosystems. Arch. Environ. Contam. Toxicol., v. 55, n. 3, p. 415-431, 2008.

SILVA, A. F. et al. Ecotoxicidade de herbicidas para a macrófita aquática (Azolla caroliniana). Planta Daninha, v. 30, n. 3, p. 541-546, 2012.

VELINI, E. D. et al. Procedimentos para instalação, avaliação e análise de experimentos, com herbicidas. Londrina: SBCPD, 1995. 42 p.

ZUCKER, E.; JOHNSON, S. L. Hazard Evaluation Division Standard Evaluation Procedure Acute toxicity test for freshwater fish. USEPA Publication, document 540/9-85006. 1985. 